\title{
Karyomorphological Studies in Some Species of Parnassia L. (Saxifragaceae s.l.) in East Asia and Intraspecific Polyploidy of $P$. palustris L.
}

\author{
Tsuneo Funamoto ${ }^{1}$ and Katsuhiko Kondo ${ }^{2}$ \\ ${ }^{1}$ Biological Institute, Showa Pharmaceutical University, Higashi tamagawagakuen, Machida City, Tokyo 194-8543, Japan \\ ${ }^{2}$ Laboratory of Plant Genetics and Breeding Science, Department of Agriculture, Faculty of Agriculture, \\ Tokyo University of Agriculture, 1734 Funako, Atsugi City, Kanagawa 243-0034, Japan
}

Correspondence should be addressed to Katsuhiko Kondo, k3kondo@nodai.ac.jp

Received 24 September 2011; Revised 29 November 2011; Accepted 26 January 2012

Academic Editor: Teresa Garnatje

Copyright ( $) 2012$ T. Funamoto and K. Kondo. This is an open access article distributed under the Creative Commons Attribution License, which permits unrestricted use, distribution, and reproduction in any medium, provided the original work is properly cited.

\begin{abstract}
Karyomorphological information is one of the most important characters for cytotaxonomy. We described karyomorphology of 14 species of Parnassia in East Asia. They had commonly the resting chromosomes of the simple chromocenter type and the mitotic prophase chromosomes of the proximal type. The somatic chromosome number of $2 n=14$ was shown in three species, that of $2 n=18$ was shown in six species, that of $2 n=18$ or 36 was shown in two species, that of $2 n=32$ was shown in one species, that of $2 n=36$ or $36+1 \sim 8$ s was shown in one species, and that of $2 n=18,27,36$ or 45 was shown in one species. They were commonly monomodal (gradual) decrease in length from the largest to the smallest chromosomes. However, their absolute chromosome sizes were different from each other. Average chromosome sizes were recognized as three types small $(1.21 \mu \mathrm{m})$, medium $(1.7-2.36 \mu \mathrm{m})$, and large (3.1-3.75 $\mu \mathrm{m})$. Parnassia palustris showed four cytotypes that could be likely cytogeographically correlated with habitats, polyploidy, and sizes of pollen grains.
\end{abstract}

\section{Introduction}

The genus Parnassia L., traditionally classified in the monotypic subfamily Parnassioideae, the family Saxifragaceae sensu lato [1], is currently placed in the family Parnassiaceae, closely related to Saxifragaceae in the order Celastrales $[2,3]$. The genus Parnassia consists of approximately 70 species [4], that are perennial herbs and grow in wet grassy plains and forests in the temperate to arctic regions of the Northern Hemisphere. Among the species of this genus, 63 species are found in China [4], five species are distributed in Russia [5] of which four species are common to China and Russia, and three species grow in Japan [6].

The chromosome numbers of 33 species of Parnassia have been documented as $2 n=18,27,32,33,34,35,36$, $37,36+1 \sim 8 s, 43,44,45,48$, and 54 including intraspecific polyploid and aneupoid (e.g., [24, 28-35]; Table 1).

The present study contributes cytological data for the species of Parnassia, mainly in its East Asian distribution range, and based on karyomorphology with respect to resting nuclei, mitotic prophase chromosomes and the mitotic metaphase chromosomes, the distribution of intraspecific polyploidy and aneuploidy, and cytogeographic patterns.

\section{Materials and Methods}

Total 400 samples of 14 species of Parnassia were collected in 75 localities in Russia, Mongolia, China, and Japan (Figure 1; Table 2) and were brought and cultivated in pots in shade place in the experimental garden of Showa Pharmaceutical University. Somatic chromosome observations were made in meristematic cells of fresh root tips. They were pretreated in $2 \mathrm{mM}$ 8-hydroxyquinoline at ca $20^{\circ} \mathrm{C}$ for 4 hours and then fixed in $45 \%$ acetic acid at ca $2^{\circ} \mathrm{C}$ for 10 minutes. They were macerated in a mixture of $45 \%$ acetic acid and $1 \mathrm{~N}$ hydrochloric acid $(1: 1)$ at ca $60^{\circ} \mathrm{C}$ for $20-23$ seconds and were then stained with $2 \%$ aceto-orcein at room temperature 
TABle 1: Chromosome numbers of Parnassia previously reported.

\begin{tabular}{|c|c|c|}
\hline Species & Chromosome number & Selected bibliography \\
\hline P. tenella Hook.f. et Thoms. & $2 n=18$ & Ding et al. 2005 [7] \\
\hline P. yunnanensis Franch. var. longistipitata Jine & $2 n=32$ & Funamoto et al. 1997 [8] \\
\hline P. esquirolii Lévl. & $2 n=18$ & Ding et al. 2005 [7] \\
\hline P. faberi Oliv. & $2 n=18$ & Ding et al. 2005 [7] \\
\hline P. chinensis Franch. & $2 n=18$ & Ding et al. 2005 [7] \\
\hline P. epunctulata J.T. Pan & $2 n=18$ & Ding et al. 2005 [7] \\
\hline$P$. venusta Jien & $2 n=18$ & Ding et al. 2005 [7] \\
\hline P. mysorensis Heyne ex Wigjt et Arn. & $2 n=18$ & Ding et al. 2005 [7] \\
\hline P. scaposa Mattf. var. yushuensis J.T. Pan & $2 n=18$ & Funamoto et al. 1996 [9] \\
\hline P. aff. cacuminum Hand.-Mazz. f. yushuensis Ku & $2 n=18$ & Funamoto et al. $2001[10]$ \\
\hline P. pusilla Wall. & $n=9$ & Malla et al. 1979 [11] \\
\hline P. oreophylla Hance & $2 n=18,36$ & Funamoto et al. 1994, $1996[10,12]$ \\
\hline P. nubicola Wall. & $n=9$ & Malla et al. $1979[11]$ \\
\hline P. subscaposa C.Y. Wu ex Ku & $2 n=18$ & Ding et al. 2005 [7] \\
\hline P. trinervis Drude & $2 n=18$ & Funamoto et al. 1996 [9]; Ding et al. 2005 [7] \\
\hline P. viridiflora Batalin & $2 n=18,36$ & Funamoto et al. $1998[13], 2001[10,13]$ \\
\hline P. laxmannii Pall. & $2 n=18,36$ & Funamoto et al. 2002 [14]; Murín et al. 1984 [15] \\
\hline P. brevistyla (Brieg) Hand.-Mazz. & $2 n=14$ & Funamoto et al. 2001 [10]; Ding et al. 2005 [7] \\
\hline P. delavayi Franch. & $2 n=14$ & Funamoto et al. 1998, 2001 [10, 13]; Ding et al. 2005 [7] \\
\hline P. alpicola Makino & $2 n=18$ & Funamoto $1986[16]$ \\
\hline P. bifolia Nekrass. & $2 n=36,36+1 \sim 8 s$ & Funamoto et al. 2002 [14]; Ding et al. 2005 [7] \\
\hline P. wightiana Wall. & $2 n=14,36$ & Funamoto et al. 1998 [13]; Malla et al. 1981 [17] \\
\hline P. monochorifolia Franch. & $2 n=48$ & Ding et al. 2005 [7] \\
\hline P. foliosa Hook.f. et Thoms. & $2 n=18$ & Funamoto $1986[16]$ \\
\hline P. grandifolia D.C. & $2 n=32$ & Gastony and Soltis 1977 [18] \\
\hline P. caroliniana Michaux & $2 n=32$ & Gastony and Soltis 1977 [18] \\
\hline P. asarifolia Vent. & $2 n=32$ & Gastony and Soltis $1977[18]$ \\
\hline P. glauca Raf. & $2 n=32,36$ & Gastony and Soltis 1977 [18]; A. Löve and D. Löve 1980 [19] \\
\hline P. palustris L. & $\begin{array}{l}2 n=18,27,32,33,34 \\
35,36,37,43,44,45,54\end{array}$ & $\begin{array}{l}\text { Hultgård } 1987 \text { [20]; Lövkvist and Hultgård } 1999 \text { [21]; } \\
\text { Funamoto et al. 2006, } 2008 \text { [22, 23] }\end{array}$ \\
\hline P. obtusiflora Rupr. & $2 n=36$ & A. Löve and D. Löve 1982 [24] \\
\hline P. kotzebuei Cham. & $2 n=18,36$ & Packer 1964 [25]; Löve and Ritchie 1966 [26] \\
\hline P. fimbriata Koenig. & $2 n=36$ & Packer $1964[25]$ \\
\hline P. townsendii Robinson & $2 n=36$ & Bye and Soltis 1979 [27] \\
\hline
\end{tabular}

in moist chamber with $45 \%$ acetic acid for ca 30 minutes and were prepared by the conventional squash method. Measurements of chromosomes in 14 species were made in each average length in several good metaphase cells.

Morphological types of the resting and the mitotic prophase chromosomes were classified for Tanaka [36, 37], and the classification of mitotic metaphase chromosomes followed Levan et al. [38]. Taxonomical treatment followed Czerepanov [5], Ku and Hultgård [4], and Akiyama [6]. The voucher specimens of the plants used in this study were deposited in Funamoto's Herbarium in Showa Pharmaceutical University.

\section{Results and Discussion}

3.1. Resting Nuclei and Mitotic Prophase Chromosomes. Fourteen species of Parnassia in East Asian (Table 2) had common karyomorphological characters in the resting and the mitotic prophase chromosomes: the resting chromosomes were classified as the simple chromocenter type which had several small heteropycnotic bodies per nucleus according to Tanaka $[36,37]$, and the mitotic prophase chromosomes were classified as the proximal type in which the early condensed segments were confined to the proximal regions of both short and long arms or short arm, showing clear condensation 
TABle 2: Chromosome numbers in 14 species of Parnassia studied here.

\begin{tabular}{|c|c|c|c|}
\hline Section & Species & Number of locality and samples & $\begin{array}{l}\text { Chromosome number } \\
\qquad(2 n)\end{array}$ \\
\hline Saxifragastrum & P. yunnanensis var. Franch. longistipitata Jien & 2 localities 17 samples & 32 \\
\hline \multirow{9}{*}{ Nectarotrilobos } & P. scaposa Mattf. var. yushuensis J.T. Pan & 5 localities 17 samples & 18 \\
\hline & P. aff. cacuminum Hand.-Mazz. f. yushuensis Ku & 1 locality 5 samples & 18 \\
\hline & P. oreophila Hance & $\begin{array}{c}3 \text { localities } 24 \text { samples } \\
1 \text { locality } 2 \text { samples }\end{array}$ & $\begin{array}{l}18 \\
36\end{array}$ \\
\hline & P. trinervis Drude & 7 localities 28 samples & 18 \\
\hline & P. viridiflora Batalin & $\begin{array}{l}1 \text { locality } 5 \text { samples } \\
1 \text { locality } 3 \text { samples }\end{array}$ & $\begin{array}{l}18 \\
36\end{array}$ \\
\hline & P. laxmannii Pall. & 2 localities 11 samples & 18 \\
\hline & P. brevistyla (Brieg) Hand.-Mazz & 2 localities 7 samples & 14 \\
\hline & P. delavayi Franch. & 2 localities 5 samples & 14 \\
\hline & P. alpicola Makino & 1 locality 1 sample & 18 \\
\hline Nectarabilobos & P. bifolia Nekrass. & $\begin{array}{c}5 \text { localities } 39 \text { samples } \\
1 \text { locality } 5 \text { samples }\end{array}$ & $\begin{array}{c}36 \\
36+1 s, 2 s, 3 s, 5 s, 7 s, 8 s^{*}\end{array}$ \\
\hline Allolobos & P. wightiana Wall. & 1 locality 4 samples & 14 \\
\hline Fimbripetalum & P. foliosa Hook.et Thoms. & 4 localities 25 samples & 18 \\
\hline Parnassia (Nectarodroson) & P. palustris L. & $\begin{array}{c}28 \text { localities } 153 \text { samples } \\
3 \text { localities } 12 \text { samples } \\
11 \text { localities } 35 \text { samples } \\
1 \text { locality } 2 \text { samples }\end{array}$ & $\begin{array}{l}18 \\
27 \\
36 \\
45\end{array}$ \\
\hline
\end{tabular}

*s: supernumerary chromosome.

TABle 3: Karyotype characters in 14 species of Parnassia observed here.

\begin{tabular}{|c|c|c|c|c|c|c|}
\hline \multirow{2}{*}{ Species } & \multirow{2}{*}{$\begin{array}{c}\text { Chromosome } \\
\text { number }(2 n)\end{array}$} & \multicolumn{4}{|c|}{ Chromosome length $(\mu \mathrm{m})$} & \multirow{2}{*}{ Form } \\
\hline & & Longest $\pm \mathrm{SD}$ & Shortest \pm SD & Total \pm SD & Average \pm SD & \\
\hline P. yunnanensis var. longistipitata & 32 & $1.6 \pm 0.1$ & $1.0 \pm 0$ & $38.6 \pm 1.1$ & $1.21 \pm 0.08$ & $\mathrm{~m}$ \\
\hline P. scaposa var. yushuensis & 18 & $2.8 \pm 0.3$ & $1.9 \pm 0.2$ & $41.2 \pm 3.8$ & $2.29 \pm 0.21$ & $m+s m$ \\
\hline P. aff. cacuminum f.yushuensis & 18 & $2.3 \pm 0.1$ & $1.5 \pm 0$ & $33.0 \pm 0.9$ & $1.83 \pm 0.07$ & $\mathrm{~m}$ \\
\hline \multirow{2}{*}{ P. oreophyla } & 18 & $2.8 \pm 0.2$ & $1.8 \pm 0.2$ & $40.6 \pm 3.2$ & $2.26 \pm 0.27$ & $m+s m$ \\
\hline & 36 & $2.8 \pm 0.3$ & $1.8 \pm 0.2$ & $78.5 \pm 4.1$ & $2.13 \pm 0.16$ & $\mathrm{~m}+\mathrm{sm}$ \\
\hline P. trinervis & 18 & $2.7 \pm 0.2$ & $2.1 \pm 0.1$ & $42.5 \pm 2.9$ & $2.36 \pm 0.19$ & $\mathrm{~m}+\mathrm{sm}$ \\
\hline \multirow{2}{*}{ P. viridiflora } & 18 & $2.0 \pm 0.1$ & $1.6 \pm 0.1$ & $30.7 \pm 1.2$ & $1.71 \pm 0.11$ & $\mathrm{~m}+\mathrm{sm}$ \\
\hline & 36 & $2.1 \pm 0.2$ & $1.4 \pm 0.1$ & $61.1 \pm 1.8$ & $1.70 \pm 0.09$ & $\mathrm{~m}+\mathrm{sm}$ \\
\hline P. laxmannii & 18 & $2.3 \pm 0.3$ & $1.6 \pm 0.1$ & $34.9 \pm 1.7$ & $1.94 \pm 0.1$ & $\mathrm{~m}$ \\
\hline P. brevistyla & 14 & $3.6 \pm 0.7$ & $2.7 \pm 0.4$ & $43.4 \pm 3.3$ & $3.10 \pm 0.25$ & $\mathrm{~m}+\mathrm{sm}$ \\
\hline P. delavayi & 14 & $4.3 \pm 0.8$ & $3.2 \pm 0.4$ & $52.5 \pm 3.6$ & $3.75 \pm 0.31$ & $\mathrm{~m}+\mathrm{sm}$ \\
\hline P. alpicola & 18 & $2.6 \pm 0.1$ & $1.9 \pm 0.1$ & $39.7 \pm 0.9$ & $2.21 \pm 0.18$ & $m+s m$ \\
\hline P. bifolia & 36 & $2.5 \pm 0.2$ & $1.6 \pm 0.1$ & $71.4 \pm 2.8$ & $1.98 \pm 0.08$ & $m+s m$ \\
\hline P. wightiana & 14 & $2.3 \pm 0.2$ & $1.4 \pm 0.1$ & $26.7 \pm 1.0$ & $1.91 \pm 0.11$ & $\mathrm{~m}+\mathrm{sm}+\mathrm{st}$ \\
\hline P. foliosa & 18 & $2.8 \pm 0.3$ & $1.9 \pm 0.2$ & $39.5 \pm 2.8$ & $2.19 \pm 0.13$ & $\mathrm{~m}+\mathrm{sm}$ \\
\hline \multirow{4}{*}{ P. palustris } & 18 & $2.7 \pm 0.2$ & $1.9 \pm 0.1$ & $41.8 \pm 3.4$ & $2.32 \pm 0.18$ & $m+s m$ \\
\hline & 27 & $2.8 \pm 0.2$ & $1.9 \pm 0.1$ & $61.2 \pm 3.9$ & $2.27 \pm 0.15$ & $\mathrm{~m}+\mathrm{sm}$ \\
\hline & 36 & $2.8 \pm 0.2$ & $1.9 \pm 0.1$ & $81.4 \pm 5.3$ & $2.27 \pm 0.13$ & $m+s m$ \\
\hline & 45 & $2.7 \pm 0.1$ & $1.8 \pm 0$ & $99.4 \pm 2.5$ & $2.21 \pm 0.07$ & $m+s m$ \\
\hline
\end{tabular}

SD: standard deviation; m: median-centromeric chromosome; sm: submedian-centromeric chromosome; st: subterminal-centromeric chromosome. 


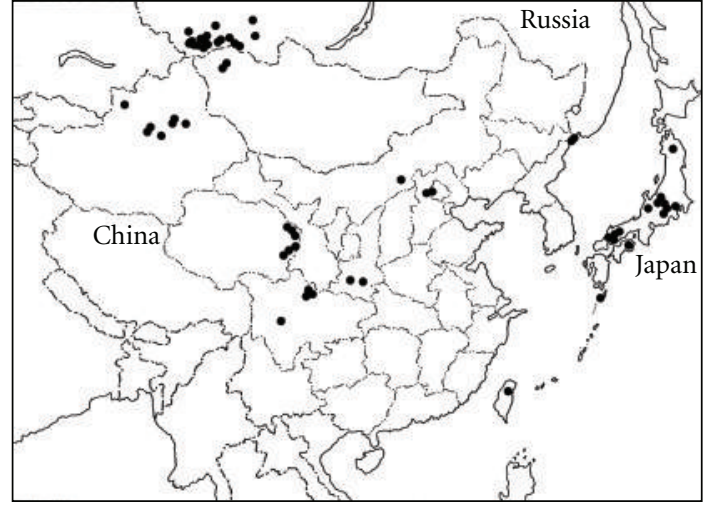

Figure 1: Collection sites of 14 species of Parnassia in China, South Siberia and Far East in Russia, Mongolian Altai, and Japan.

transition from the proximal to the distal regions (Tanaka [36, 37]; Figure 2). There was no difference in the resting and the mitotic prophase chromosome types among in these 14 species, thus it was concluded that the genus Parnassia had the simple chromocenter types at the resting nucleus and the proximal types at the mitotic prophase chromosomes.

3.2. The Mitotic Metaphase Chromosomes. Chromosome numbers in 33 species of Parnassia were from $2 n=14$ to $2 n=54$ (Table 1$)$. Three species had the somatic chromosome number of $2 n=14$, five species had that of $2 n=32$, one species had that of $2 n=48$, and the other 24 species had that of $2 n=18$. Intraspecific polyploids were found in $P$. oreophylla, $P$. viridiflora, $P$. laxmannii, $P$. palustris, and $P$. obtusiflora, while intraspecific aneuploids were found in P. bifolia, P. wightiana, $P$. glauca, and $P$. palustris (Table 1). Particularly, Parnassia palustris had various chromosome numbers from $2 n=18$ to 54 (e.g., [34, 35]; Table 1). Parnassia brevistyla (Figure $3(\mathrm{j}))$, P. delavayi (Figure $3(\mathrm{k})$ ), and P. wightiana (Figure $3(\mathrm{n})$ ) had $2 n=14$, $P$. scaposa var. yushuensis (Figure $3(\mathrm{~b})), P$. aff. cacuminum f. yushuensis (Figure 3(c)), P. trinervis (Figure 3(f)), P. laxmannii (Figure 3(i)), P. alpicola (Figure 3(1)), and P. foliosa (Figure $3(\mathrm{o})$ ) had $2 n=18, P$. oreophylla (Figures $3(\mathrm{~d}$ ) and $3(\mathrm{e})$ ) and $P$. viridiflora (Figures $3(\mathrm{~g})$ and $3(\mathrm{~h})$ ) had $2 n=18$ and $36, P$. palustris had $2 n=18,27,36$, and 45 (Figures 3(p)-3(s)), P. yunnanensis var. longistipitata had $2 n=32$ (Figure $3(\mathrm{a})$ ), and P. bifolia had $2 n=36$ and $36+1 \sim 8$ s (Figures $3(\mathrm{~m})$ and 4 ). Parnassia palustris in a plant collected in Scandinavia by Hultgård [20] and Lövkvist and Hultgård [21] was very rarely documented to have the chromosome numbers of $2 n=27$ and 45 . The chromosome number of $2 n=14$ for $P$. wightiana [13] was different from the previous counts of $2 n=36$ [17] and $2 n=32$ [18], while that of $P$. glauca was also different from the previous count of $2 n=36$ [19]. Thus, these two species are necessary to have more cytological studies. A peculiar chromosome number of $2 n=14$ for Chinese species of Parnassia was reported by Funamoto et al. $[10,13]$ and Ding et al. [7]. The chromosome number of $2 n=32$ was previously reported in four North American species of
Parnassia such as P. gandifolia, P. caroliniana, P. asarifolia, and P. glauca by Gastony and Soltis [18] and that was also found in Chinese species [8].

Aneuploid chromosome numbers of $2 n=36+1 \sim 8$ s for $P$. bifolia could include supernumerary chromosomes since these aneuploid plants had high pollen stainabilities (87.5$98.6 \%)$.

3.3. Chromosome Sizes and Basic Chromosome Numbers. Morphological characters of chromosomes in chromosome numbers, chromosome sizes, chromosome complements in centromeric positions, and chromosome alignment from the longest to the shortest one are important information for cytotaxonomy. The chromosome number of $2 n=14$ was considered diploid $x=7$, that of $2 n=32$ was considered tetraploid $x=8$, and that of $2 n=18$ and 36 was considered diploid and tetraploid $x=9$, respectively, if these basic chromosome numbers of $x=7,8$, and 9 were accepted. Plants of the basic chromosome number of $x=7$ are found in China, those of $x=8$ are found in China and North America, and those of $x=9$ are commonly found in the world. Their karyotypes had commonly monomodal gradation in chromosome length from the longest to the shortest chromosomes and had median and submedian centromeric chromosomes, rarely median, submedian, and subterminal centromeric chromosomes (Table 3; Figure 5). Thus, Parnassia could be divided by four groups at least from chromosome characters mentioned above. (1) Smallsized and median-centromeric chromosomes ranged from 1.6 to $1.0 \mu \mathrm{m}$ long with average $1.21 \mu \mathrm{m}$ long, and had the base number of $x=8$. (2) Medium-sized and medianand submedian-centromeric chromosomes ranged from 2.8 to $1.9 \mu \mathrm{m}$ long with average $2.29 \mu \mathrm{m}$ long and had the base number of $x=9$. (3) Large-sized and medianand submedian-centromeric chromosomes ranged from 3.6 to $2.7 \mu \mathrm{m}$ long with average $3.10 \mu \mathrm{m}$ long and had the base number of $x=7$. (4) Medium-sized and median-, submedian-, and subterminal-centromeric chromosomes ranged from 2.3 to $1.4 \mu \mathrm{m}$ long with average $1.91 \mu \mathrm{m}$ long, and had the base number of $x=7$. These cytotaxonomical groupings were not agreed with the taxonomical treatment by $\mathrm{Ku}$ [39]. More cytological information and another new technique are necessary to clarify and justify the cytosystematic relationships of Parnassia.

3.4. Intraspecific Polyploid and Aneuploid. Intraspecific polyploid of $2 n=18$ and 36 for P. oreophylla, P. viridiflora, and P. laxmannii, and that of $2 n=18,27,36,45$, and 54 for $P$. palustris were reported, especially this polyploidy for $P$. palustris was found in Scandinavia [20,21] and Great Britain $[34,35]$, and $2 n=27$ and 45 chromosomes were also found in Russia [22, 23]. For example, 156 samples of this species were collected in 23 localities in Altai Mountains, Tuva and Krasunoyarsk region in Russia, of which 113 samples $(72.4 \%)$ in 18 sites had $2 n=18$ chromosomes, 12 samples $(7.7 \%)$ in three sites had $2 n=27$ chromosomes, 29 samples $(18.6 \%)$ in five sites had $2 n=36$ chromosomes, and two samples $(1.3 \%)$ in one site had $2 n=45$ chromosomes (Figure 6; [22, 23]; Funamoto and Smirnov unpublished). 


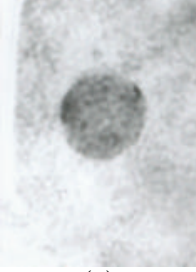

(a)

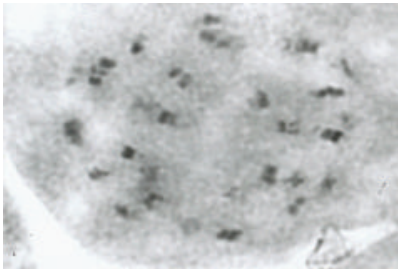

(a')

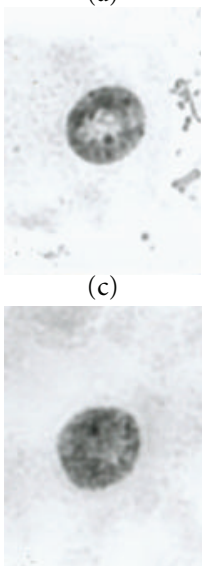

(e)

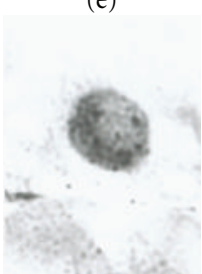

(g)

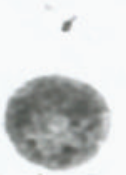

(i)

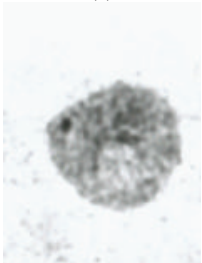

(k)

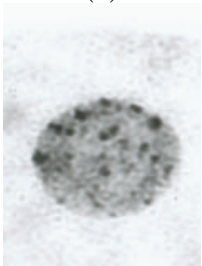

(m)

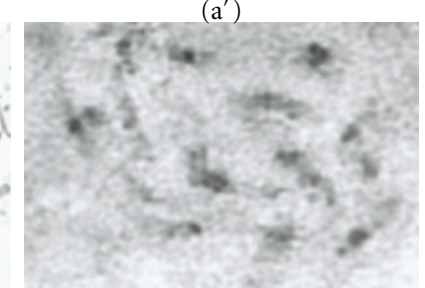

(c')

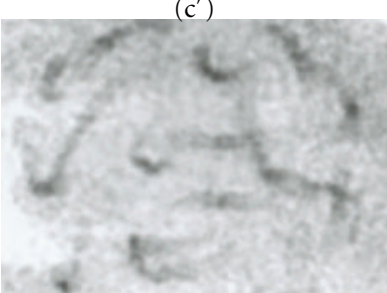

$\left(\mathrm{e}^{\prime}\right)$

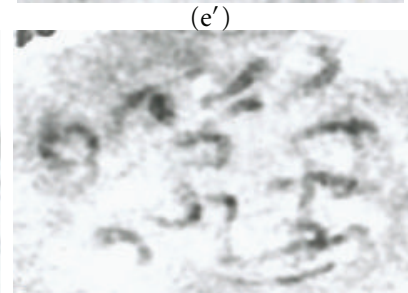

$\left(\mathrm{g}^{\prime}\right)$

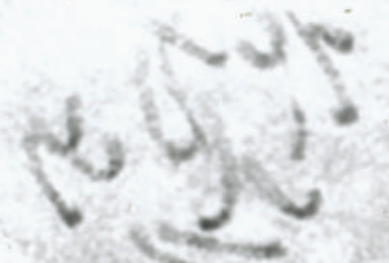

$\left(i^{\prime}\right)$

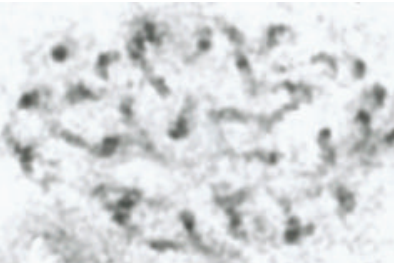

$\left(\mathrm{k}^{\prime}\right)$

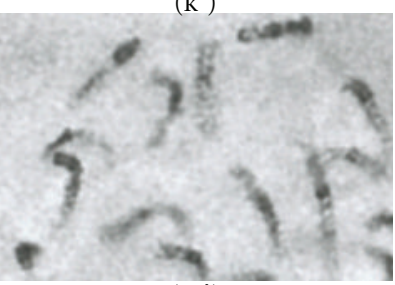

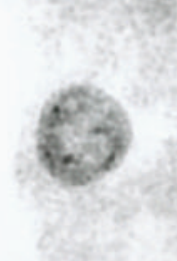

(b)

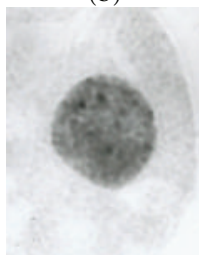

(d)

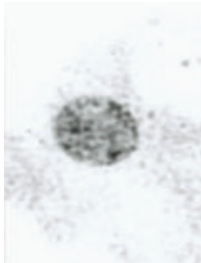

(f)

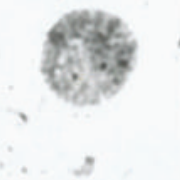

(h)

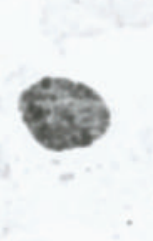

(j)

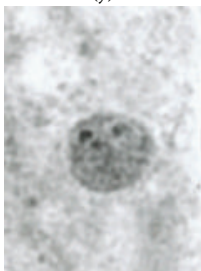

(1)

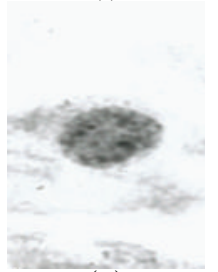

(n)

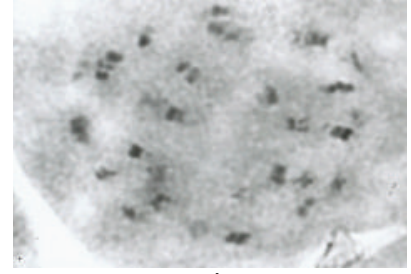

(b')

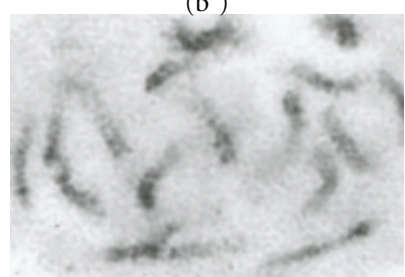

(d')

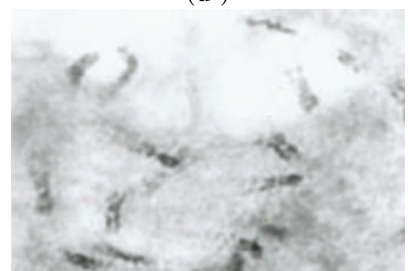

$\left(f^{\prime}\right)$

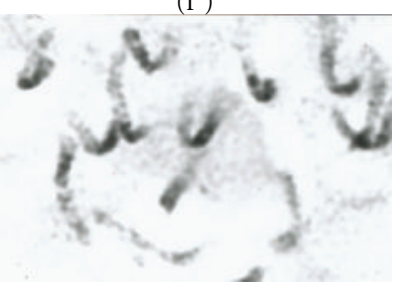

$\left(\mathrm{h}^{\prime}\right)$

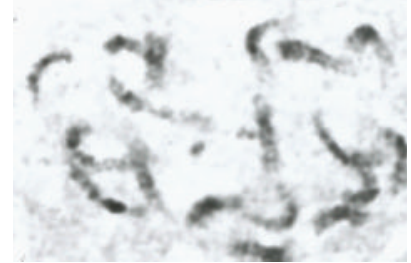

$\left(\mathrm{j}^{\prime}\right)$

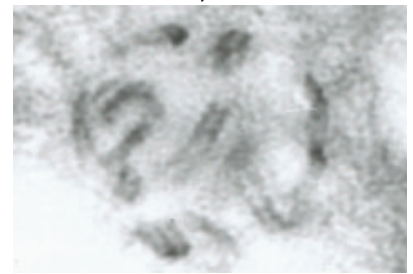

$\left(1^{\prime}\right)$

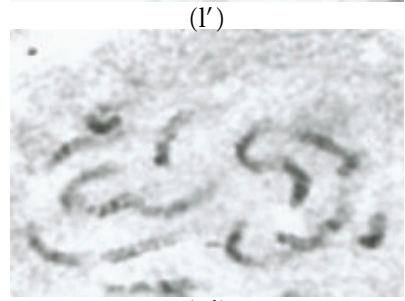

$\left(n^{\prime}\right)$

Figure 2: Karyomorphological comparisons of resting and mitotic prophase chromosomes in 14 species of Parnassia. (a)-(n) The resting chromosomes; $\left(\mathrm{a}^{\prime}\right)-\left(\mathrm{n}^{\prime}\right)$ the mitotic prophase chromosomes. (a) and $\left(\mathrm{a}^{\prime}\right)$ P. yunnanensis var. longistipitata; (b) and ( $\left.\mathrm{b}^{\prime}\right)$ P. scaposa var. yushuensis; (c) and ( $\left.\mathrm{c}^{\prime}\right)$ P. aff. cacuminum $\mathrm{f}$. yushuensis; $(\mathrm{d})$ and $\left(\mathrm{d}^{\prime}\right)$ P. oreophylla; $(\mathrm{e})$ and $\left(\mathrm{e}^{\prime}\right)$ P. trinervis; (f) and ( $\left.\mathrm{f}^{\prime}\right)$ P. viridiflora; ( $\mathrm{g}$ ) and $\left(\mathrm{g}^{\prime}\right)$ P. laxmannii; $(\mathrm{h})$ and $\left(\mathrm{h}^{\prime}\right)$ P. brevistyla; $(\mathrm{i})$ and $\left(\mathrm{i}^{\prime}\right)$ P. delavayi; $(\mathrm{j})$ and $\left(\mathrm{j}^{\prime}\right)$ P. alpicola; $(\mathrm{k})$ and $\left(\mathrm{k}^{\prime}\right)$ P. bifolia; $(\mathrm{l})$ and $\left(\mathrm{l}^{\prime}\right)$ P. wrightiana; $(\mathrm{m})$ and $\left(\mathrm{m}^{\prime}\right)$ P. foliosa; $(\mathrm{n})$ and $\left(\mathrm{n}^{\prime}\right)$ P. palustris. Scale bar $=5 \mu \mathrm{m}$. 


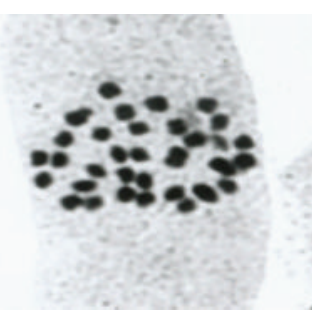

(a)

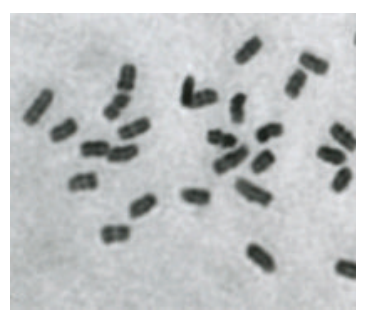

(e)

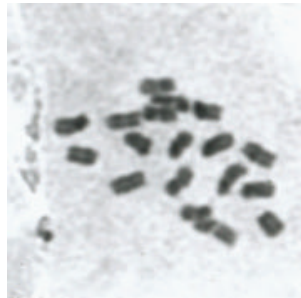

(i)

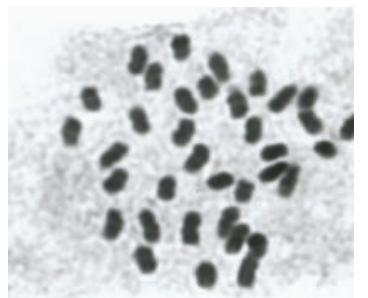

(m)

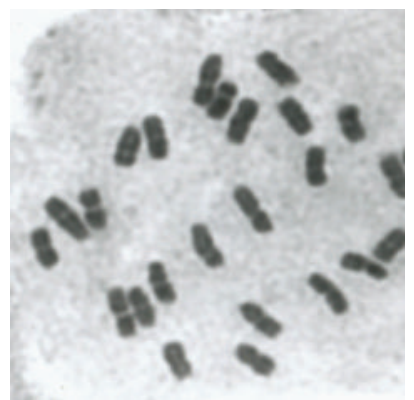

(q)

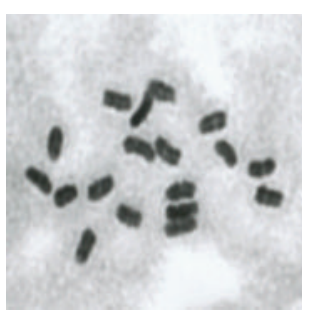

(b)

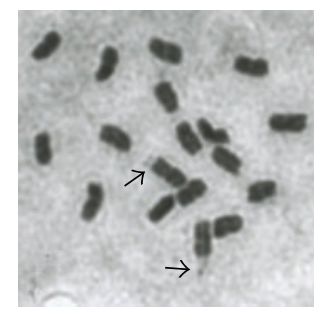

(f)

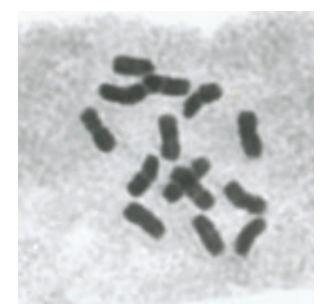

(j)

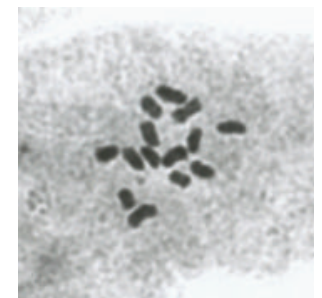

(n)

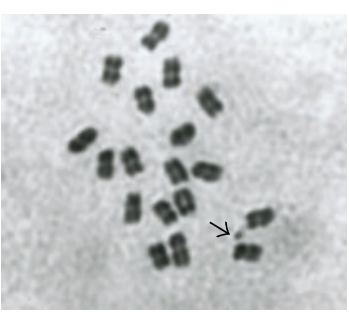

(c)

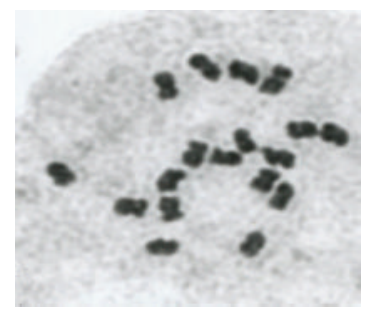

(g)

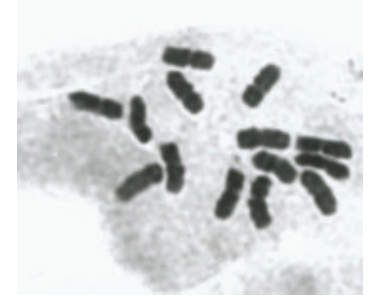

(k)

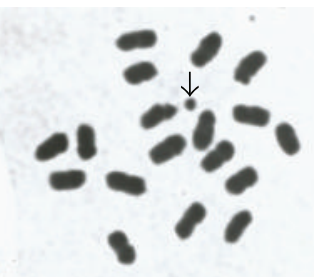

(o)

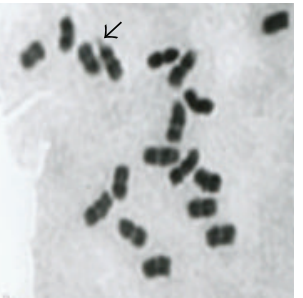

(d)

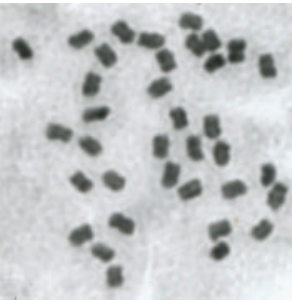

(h)

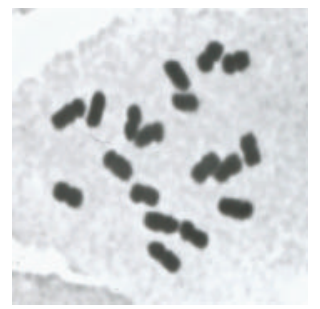

(l)

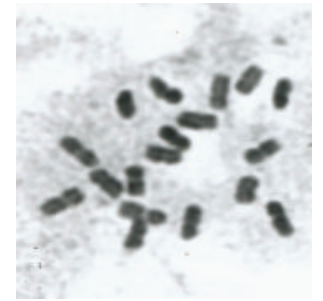

(p)

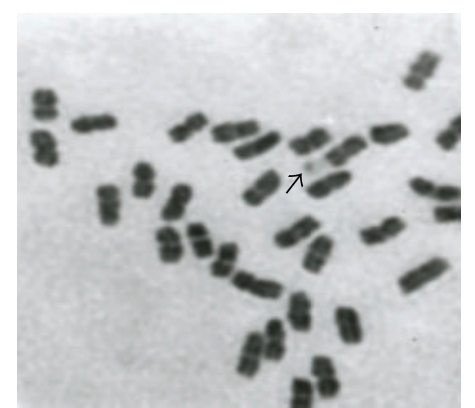

$(\mathrm{r})$

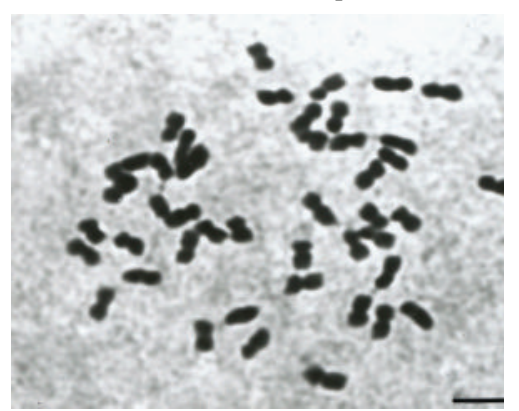

(s)

Figure 3: Somatic metaphase chromosomes in 14 species of Parnassia. (a) P. yunnanensis var. longistipitata (2n = 32); (b) P. scaposa var. yushuensis $(2 n=18)$; (c) P. aff. cacuminum f. yushuensis $(2 n=18)$; (d) and (e) P. oreophylla ((d) $2 n=18$; (e) $2 n=36)$; (f) P. trinervis $(2 n=18) ;(\mathrm{g})$ and (h) P. viridiflora $((\mathrm{g}) 2 n=18$; (h) $2 n=36) ;(\mathrm{i})$ P. laxmannii $(2 n=18) ;(\mathrm{j})$ P. brevistyla $(2 n=14) ;(\mathrm{k})$ P. delavayi $(2 n=14)$; (l) P. alpicola $(2 n=18) ;(\mathrm{m})$ P. bifolia $(2 n=36) ;(\mathrm{n})$ P. wrightiana $(2 n=14)$; (o) P. foliosa $(2 n=18)$; (p) to (s) P. palustris ((p) $2 n=18$; (q) $2 n=27$; (r) $2 n=36$; (s) $2 n=45$ ). Arrow points satellite. Scale bar $=5 \mu \mathrm{m}$.

According to pollen stainability and sizes of pollen grains of Parnassia palustris, plants of $2 n=18$ and 36 had high pollen stainabilities $(81.4-98.2 \%)$, while those of $2 n=27$ and 45 had very low pollen stainabilities $(0.74-0.85 \%)$. Sizes of pollen grains of the species were $27.3-30.3 \mu \mathrm{m} \times 25.8-$ $28.1 \mu \mathrm{m}$ in plants of $2 \mathrm{n}=18,30.1-32.5 \mu \mathrm{m} \times 27.6-30.2 \mu \mathrm{m}$ in plants of $2 n=27$, and $31.8-33.6 \mu \mathrm{m} \times 30.1-31.3 \mu \mathrm{m}$ in plants of $2 n=36$, respectively. Significant $t$-test in sizes 


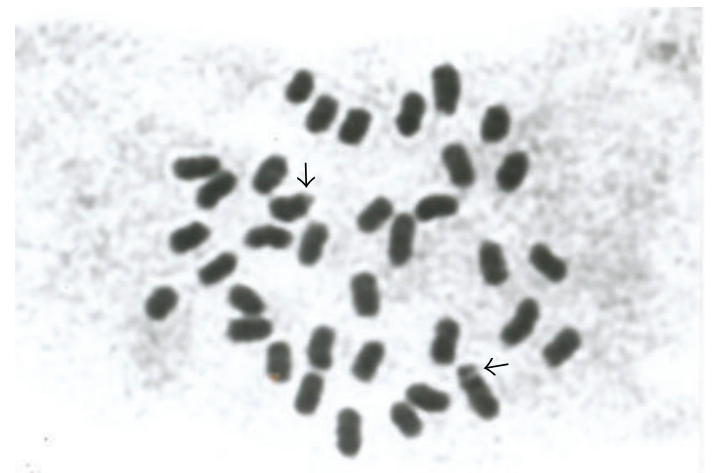

(a)

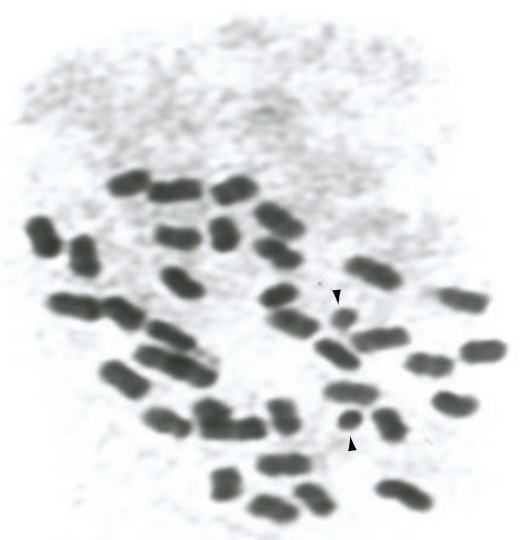

(c)

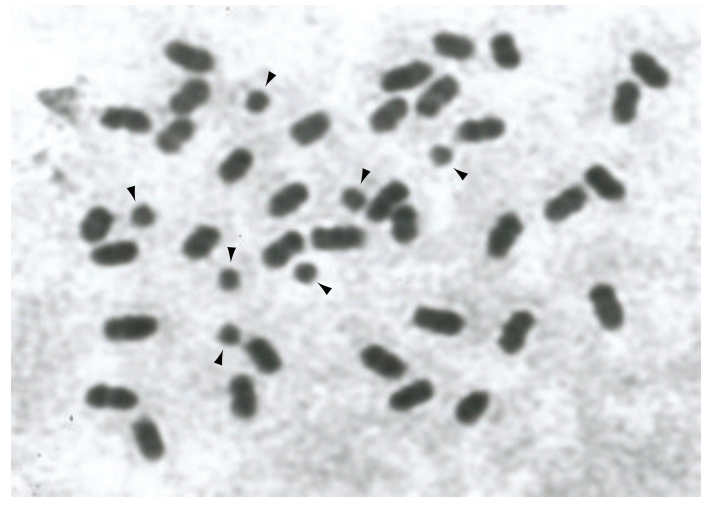

(f)

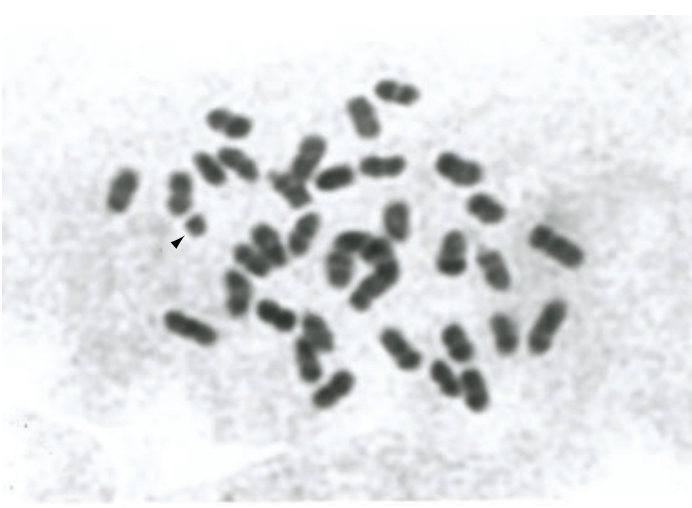

(b)

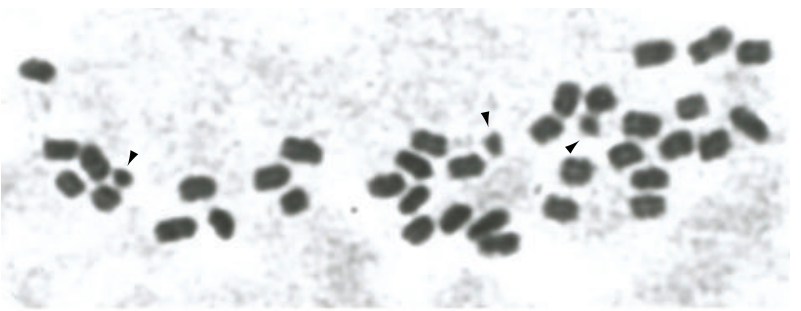

(d)

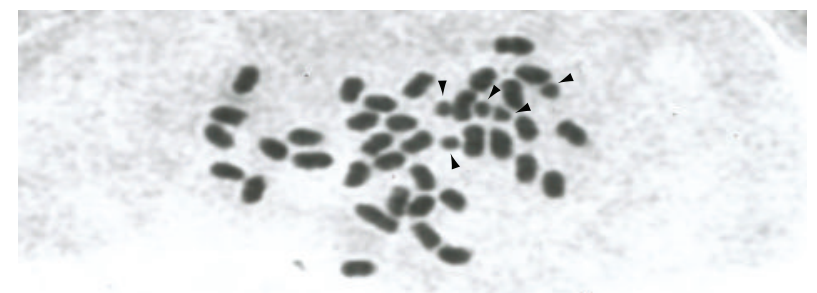

(e)

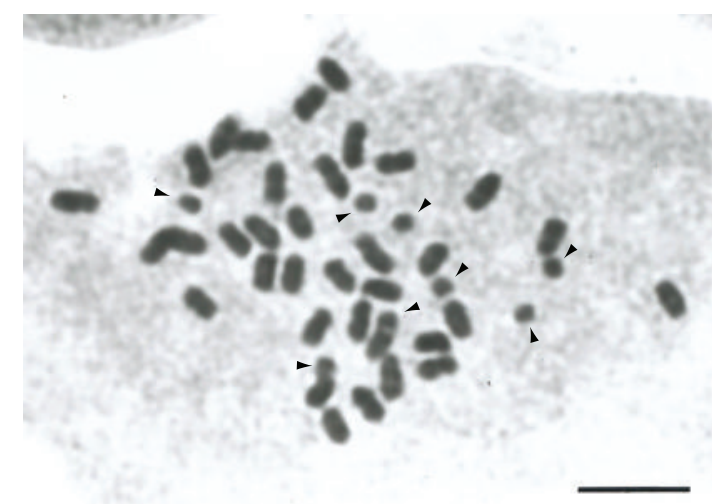

(g)

FIgURE 4: Variations of supernumerary chromosomes of Parnassia bifolia. Arrow indicates satellites and arrows head indicates supernumerary chromosomes. (a) $2 n=36$. (b) $2 n=36+1 \mathrm{~s}$; (c) $2 n=36+2 \mathrm{~s}$; (d) $2 n=36+3 \mathrm{~s}$; (e) $2 n=36+5 \mathrm{~s}$; (f) $2 n=36+7 \mathrm{~s}$; (g) $2 n=36+8 \mathrm{~s}$. (s) supernumerary chromosomes. Scale bar $=5 \mu \mathrm{m}$.

of pollen grains showed significant difference between the plants of $2 n=18$ and $2 n=36$ with $P<0.05$ and $P<0.01$ levels, respectively. Sizes of pollen grains could be correlated with polyploid levels $[22,23]$. Similar results were reported with Japanese Deutzia crenata [40-42] and Japanese Hydrangea paniculata [43].
The plants with the chromosome number of $2 n=18$ were commonly found along the vegetation edges such as in the disturbed riverine, forest meadows and tundra in Russian and Mongolian Altai, and Tuva in Russia, those with the chromosome number of $2 n=27$ were found in placid lake side and together with the plants of the chromosome number 


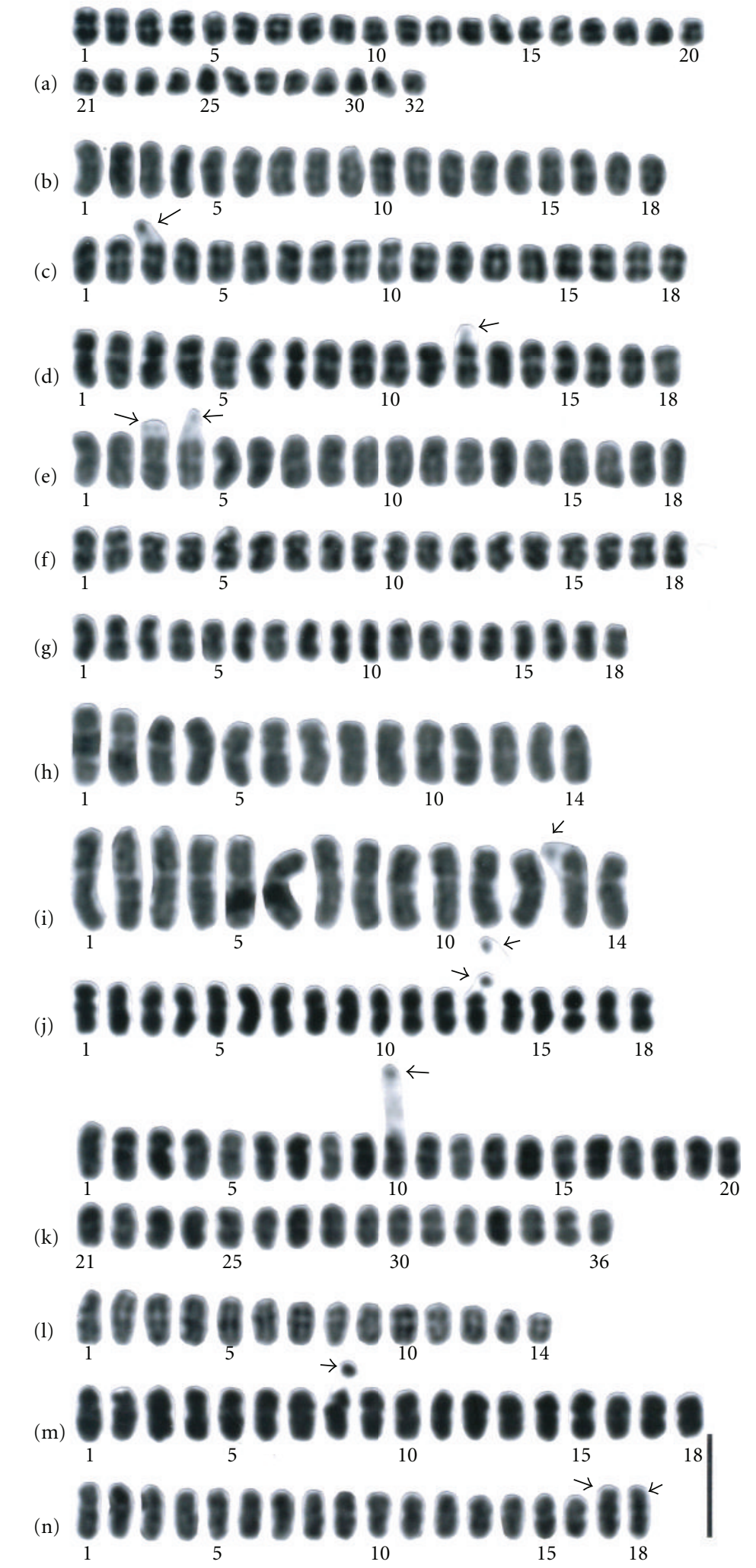

FIgURE 5: Karyotype comparisons in 14 species of Parnassia. (a) P. yunnanensis var. longistipitata; (b) P. scaposa var. yushuensis; (c) P. aff. cacuminum f. yushuensis; (d) P. oreophylla; (e) P. trinervis; (f) P. viridiflora; (g) P. laxmannii; (h) P. brevistyla; (i) P. delavayi; (j) P. alpicola; (k) P. bifolia; (l) P. wightiana; (m) P. foliosa; (n) P. palustris. Arrows indicate satellites. Scale bar $=5 \mu \mathrm{m}$. 


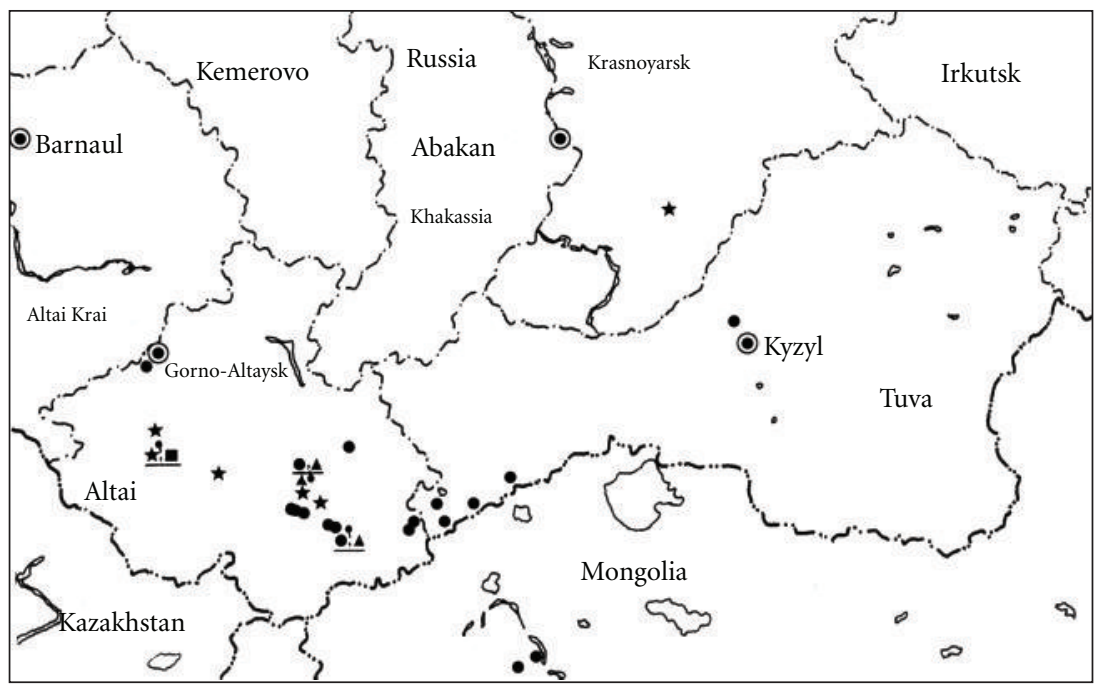

FIGURE 6: Map of collection sites and polyploidy of Parnassia palustris in Altai Mountains and the adjacent regions. Chromosome numbers of $2 n=18(\bullet), 2 n=27(\boldsymbol{\Delta}), 2 n=36(\star)$, and $2 n=45(\boldsymbol{\square})$.

$2 n=18$ in Russian Altai, while those with the chromosome number of $2 n=36$ were commonly found in narrow stream in mountain slope and mountain meadows in Russian Altai and Krasnoyarsk Region in Russia, and those with the chromosome number of $2 n=45$ were rarely found together with the plants with the chromosome number of $2 n=36$ in Russian Altai. Thus, Parnassia palustris in Altai Mountains and adjacent regions in Russia seemed one of the welldiversified species with respect to chromosome characters. These cytological phenomena speculated that the two plant strains with the chromosome numbers of $2 n=27$ and $2 n=$ 45 might be isolated by pollination between nondisjunction diploid gametes producing diploid and tetraploid ovules $(2 \mathrm{x}$ and $4 \mathrm{x}$ ) and normal male gamete for diploid pollen $(\mathrm{x})$, since any plant with the chromosome number of $2 n=27$ has never been found within the populations of the plants with the chromosome number of $2 n=36$. This factor might be caused by various geographical conditions and extremes of climate temperature $[22,23]$.

\section{Acknowledgments}

The authors wish to express sincere appreciation to Professor Dr. Joan Vallés, Barceona University for a long-term leadership of the field of chromosome botany and to commemorate his celebration of retirement. They thank many Chinese, Russian, and Mongolian botanists for guiding their field trips and identifying plant materials. This study was supported by the Grant-in-Aid for the Monbusho International Research Program-Joint Research no. 04044128 (the representative: Ryuso Tanaka) and no. 06044160 (the representative: Katsuhiko Kondo) to the Ministry of Education, Science, Sports and Culture of Japan, and the Grant-in-Aid for Scientific Research Program (A) (1) no. 10044209, no. 14255014, and no. 19255004 (the representative: Katsuhiko Kondo) of the Japan Society for the Promotion of Science.

\section{References}

[1] A. Engler, "Unterfam. IV. Parnassioideae," in Die Natürlichen Pflanzenfamilien, pp. 178-182, 1930.

[2] B. Bremer, K. Bremer, M. W. Chase et al., "An update of the Angiosperm Phylogeny Group classification for the orders and families of flowering plants: APG III," Botanical Journal of the Linnean Society, vol. 161, no. 2, pp. 105-121, 2009.

[3] K. Yonekura, Koutou Shokubutsu Bunruihyou, Hokuryukan, Japan, 2009.

[4] T.-C. Ku and U. M. Hultgård, "Parnassia linnaeus," in Flora of China, Vol. 8, Z.-Y. Wu and P. H. Raven, Eds., pp. 358-379, Science Press, Beijing, China, 2001.

[5] S. K. Czerepanov, "Parnassia L.," in Vascular Plants of Russia and Adjacent States (the Former USSR), S. K. Czerepanov, Ed., p. 335, Cambridge University Press, New York, NY, USA, 1995.

[6] S. Akiyama, "Parnassia L.," in Flora of Japan, Vol. IIb, K. Iwatsuki, D. E. Boufford, and H. Ohba, Eds., pp. 38-39, Kodansha, Japan, 2001.

[7] W. Ding, H. Wang, D. Z. Li, and J. M. Lu, "Cytological studies of 14 Chinese species of Parnassia L. (Parnassiaceae) and its phylogenetic implications," Caryologia, vol. 58, no. 3, pp. 201211, 2005.

[8] T. Funamoto, K. Kondo, D.-Y. Hong, S.-L. Zhou, and T. Shimada, "Karyomorphological studies in Parnassia yunnanensis var. longistipitata in Sichuan Province, China," Chromatographic Science, vol. 1, pp. 21-24, 1997.

[9] T. Funamoto, K. Kondo, D.-Y. Hong et al., "Karyomorphological studies in Chinese Parnassia (II). Three species in Qinghai Province," La Kromosomo, vol. 2, no. 82, pp. 2845-2854, 1996.

[10] T. Funamoto, K. Kondo, D.-Y. Hong, S.-L. Zhou, and H. Ogura, "Chromosomes in four species of Parnassia (Saxifragaceae) in the northern part of Sichuan Province, China," Chromatographic Science, vol. 5, pp. 19-25, 2001.

[11] S. B. Malla, S. Bhattarai, M. Gorkhali, H. Saiju, and M. Kayastha, in IOPB Chromosome Number Reports LXV, vol. 28, pp. 627-628, Taxon, 1979.

[12] T. Funamoto, R. Tanaka, D.-Y. Hong, Y.-B. Luo, and M. Nakata, "Karyomorphological studies in Chinese Parnassia. 
Two species in North China region," La Kromosomo, vol. 2, no. 74, pp. 2576-2582, 1994.

[13] T. Funamoto, K. Kondo, D.-Y. Hong, S.-L. Zhou, and H. Deguchi, "A chromosome study of three Parnassia species collected in the Qin Ling Mountains, Shaanxi Province, China," Chromatographic Science, vol. 2, pp. 111-115, 1998.

[14] T. Funamoto, K. Kondo, D.-Y. Hong, S. Ge., J.-F. Mao, and H. Ogura, "Somatic chromosomes of three Parnassia species (Saxifragaceae) in Xinjiang, China," Chromatographic Science, vol. 6, pp. 27-34, 2002.

[15] A. Murín, I. Háverová, and C. Zamsran, "Further karyological studies of the Mongorian flora," Folia Geobotanica et Phytotaxonomica, vol. 19, pp. 28-39, 1984.

[16] T. Funamoto, "Karyomorphological studies of the genus Parnassia in Japan," Science Report of the Research Institute of Evolutionary Biology, vol. 3, pp. 72-81, 1986.

[17] S. B. Malla, S. Bhattarai, M. Gorkhali, H. Saiju, and M. Kayastha, in Chromosome Number Reports LXX, vol. 30, p. 75, Taxon, 1981.

[18] G. Gastony and D.E. Soltis, "Chromosome studies of Parnassia and Lepuropetalon (Saxifragaceae) from the eastern United States. A new base number of Parnassia," Rhodora, vol. 79, pp. 573-557, 1977.

[19] A. Löve and D. Löve, in IOPB Chromosome Number Reports, LXIX, vol. 29, pp. 709-710, Taxon, 1980.

[20] U. M. Hultgård, "Parnassia palustris L. in Scandinavia," Symbolae botanicae Upsalienses, vol. 28, pp. 1-128, 1987.

[21] B. Lövkvist and U. M. Hultgård, "Chromosome numbers in South Swedish vascular plants," Opera Botanica, no. 137, pp. $1-42,1999$.

[22] T. Funamoto, K. Kondo, I.V. Tatarenko, A. Gontcharov, V.P. Verkholat, and S.V. Smirnov, "Intraspecific polyploidy of Parnassia palustris var. multiseta (Saxifragaceae s.l.) collected in Primorye and Altai Territories, Russia," Chromatographic Science, vol. 1, pp. 23-26, 2006.

[23] T. Funamoto, K. Kondo, S.V. Smirnov, T. Motohashi, Y. Hoshi, and O. Damdinsuren, "Once more: intraspecific polyploidy of Parnassia palustris var. multiseta (Saxifragaceae sensu lato) collected in the Altai Mountains in Russia and Mongolia," Chromosome Botany, vol. 3, no. 3-4, pp. 73-77, 2008.

[24] A. Löve and D. Löve, in IOPB Chromosome Number Reports LXXV, vol. 31, p. 344, Taxon, 1982.

[25] J. G. Packer, "Chromosome numbers and taxonomic notes on western Canadian and Arctic plants," Canadian Journal of Botany, vol. 42, pp. 473-494, 1964.

[26] A. Löve and J. C. Ritchie, "Chromosome numbers from central Canada," Canadian Journal of Botany, vol. 44, pp. 429-439, 1966.

[27] R. A. Bye Jr. and D. E. Soltis, "Parnassia towsendii (Saxifragaceae), a Mexican endemic,” The Southwestern Naturalist, vol. 24 , no. 2, pp. 209-222, 1979.

[28] Z. Wada, "Karyological studies in a few plants of some tablelands (Preliminary note)," The Japanese Journal of Genetics, vol. 30, p. 191, 1958.

[29] R. L. Taylor and G. A. Mulligan, Flora of the Queen Charlotte Islands. Part 2. Cytological Aspects of the Vascular Plants, Queen's Printer, Ottawa, Canada, 1968.

[30] A. W. Johnson and J. G. Packer, "Chromosome numbers in the flora of Ogotruk Creek, N.W. Alaska," Botaniska Notiser, vol. 121, pp. 403-445, 1968.

[31] P. G. Zhukova, V. V. Petrovsky, and T. N. Plieva, "The chromosome numbers and taxonomy of some plant species from Siberia and Far East," Botanicheskiy Zhurnal, vol. 58, pp. 1331-1342, 1973 (Russian).
[32] R. E. Krogulevich, "Karyological analysis of the species of the flora of eastern Sayan," in Flora of the Prebaikal, L. I. Malyshev and G. A. Peshlcova, Eds., pp. 19-48, Novosibirsk, Russia, 1978.

[33] A. Murín, I. Háverová, and C. Zamsran, "Karyological studies of some species of the Mongolian flora," Folia Geobotanica et Phytotaxonomica, vol. 15, pp. 395-405, 1980.

[34] R. J. Gornall and J. E. Wentworth, "Variation in the chromosome number of Parnassia palustris L. in the British Isles," New Phytologist, vol. 123, pp. 383-388, 1993.

[35] J. E. Wentworth and R. J. Gornall, "Cytogenetic evidence for autopolyploidy in Parnassia palustris," New Phytologist, vol. 134, no. 4, pp. 641-648, 1996.

[36] R. Tanaka, "Types of resting nuclei in Orchidaceae," Botanical Magazine Tokyo, vol. 84, pp. 118-122, 1971.

[37] R. Tanaka, "Recent karyotype studies," in Plant Cytology, K. Ogawa, K. Kurozumi, S. Koike, and S. Sato, Eds., pp. 293-326, Asakura Book, Tokyo, Japan, 1977.

[38] A. Levan, K. Fredga, and A. A. Sandberg, "Nomenclature for centromeric position on chromosomes," Hereditas, vol. 52, pp. 201-220, 1964.

[39] T.-C. Ku, "Parnassioideae Engl," in Flora Reipublica Popularis Science Tomus 35 (1), Angeospermae Dicotyledoneae Saxifragaceae (2), L. Lu and S. Hwang, Eds., pp. 1-66, Science Press, Beijing, China, 1995.

[40] T. Funamoto and T. Nakamura, "Cytogeographical study of Deutzia crenata in Japan (Saxifragaceae)," La Kromosomo, vol. 2, no. 75-76, pp. 2624-2630, 1994.

[41] L. M. Niu and H. Ohba, "Taxonomic studies of Deutzia Thunb. (Saxifragaceae s. 1.) in Japan 1. chromosome numbers," Journal of Japanese Botany, vol. 75, no. 2, pp. 80-88, 2000.

[42] L. M. Niu and H. Ohba, "Taxonomic studies of Deutzia (Saxifragaceae, s. l.) in Japan 2. Pollen grains," Journal of Japanese Botany, vol. 76, no. 2, pp. 84-95, 2001.

[43] T. Funamoto and M. Ogawa, "A cytogeographical study in Hydrangea paniculata Sieb (Saxifragaceae s.l.) in Japan," Chromatographic Science, vol. 6, no. 3, pp. 73-82, 2002. 

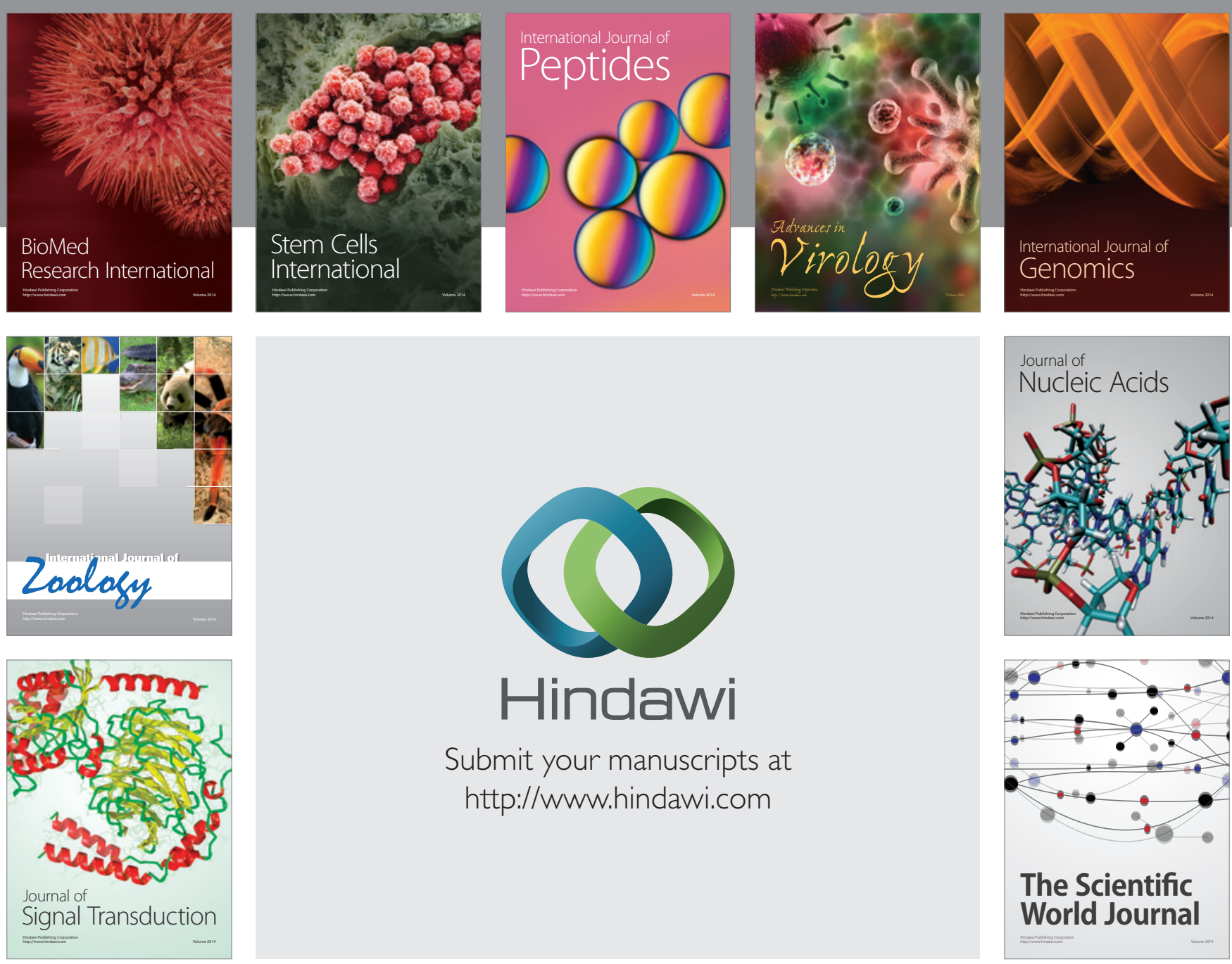

Submit your manuscripts at

http://www.hindawi.com
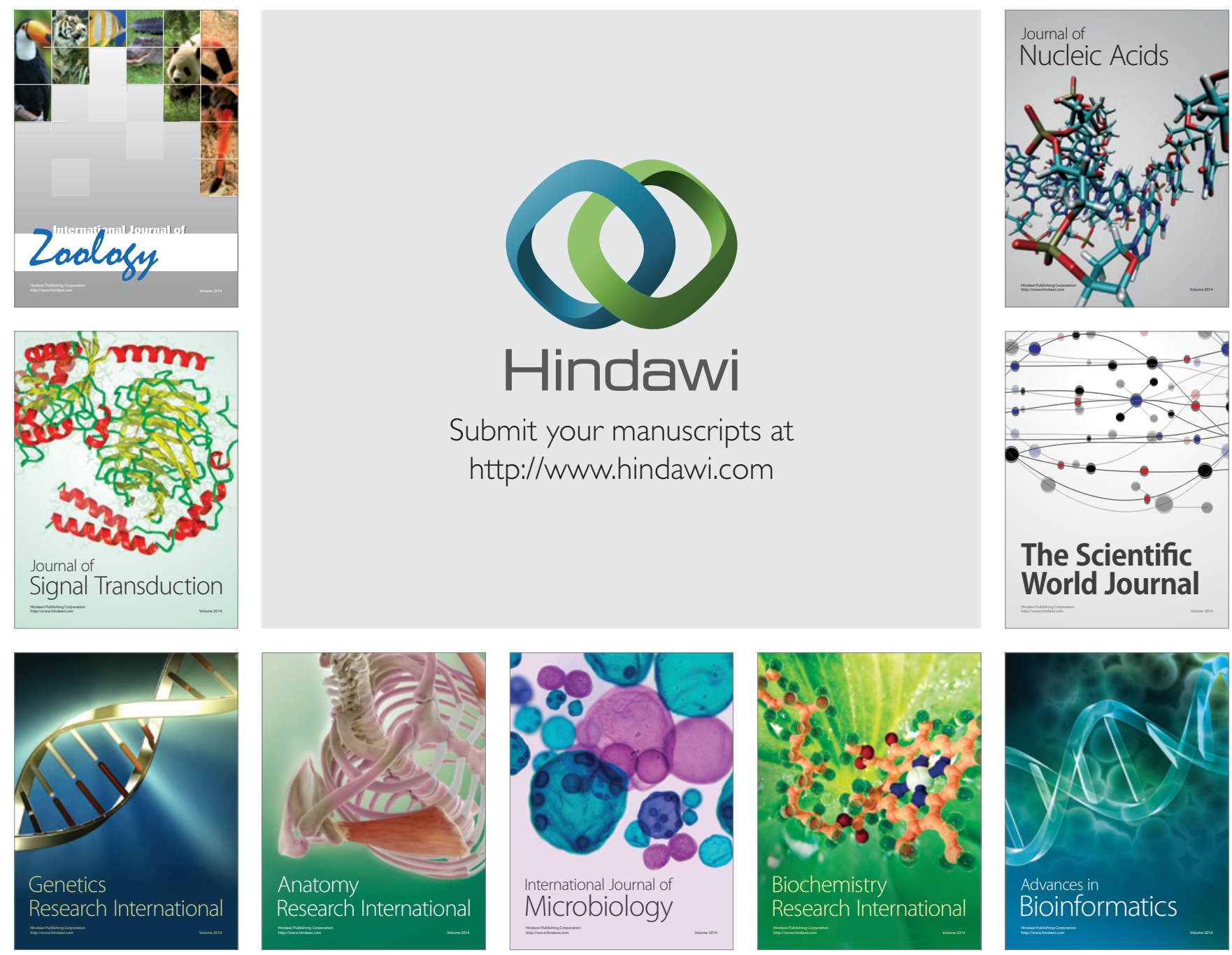

The Scientific World Journal
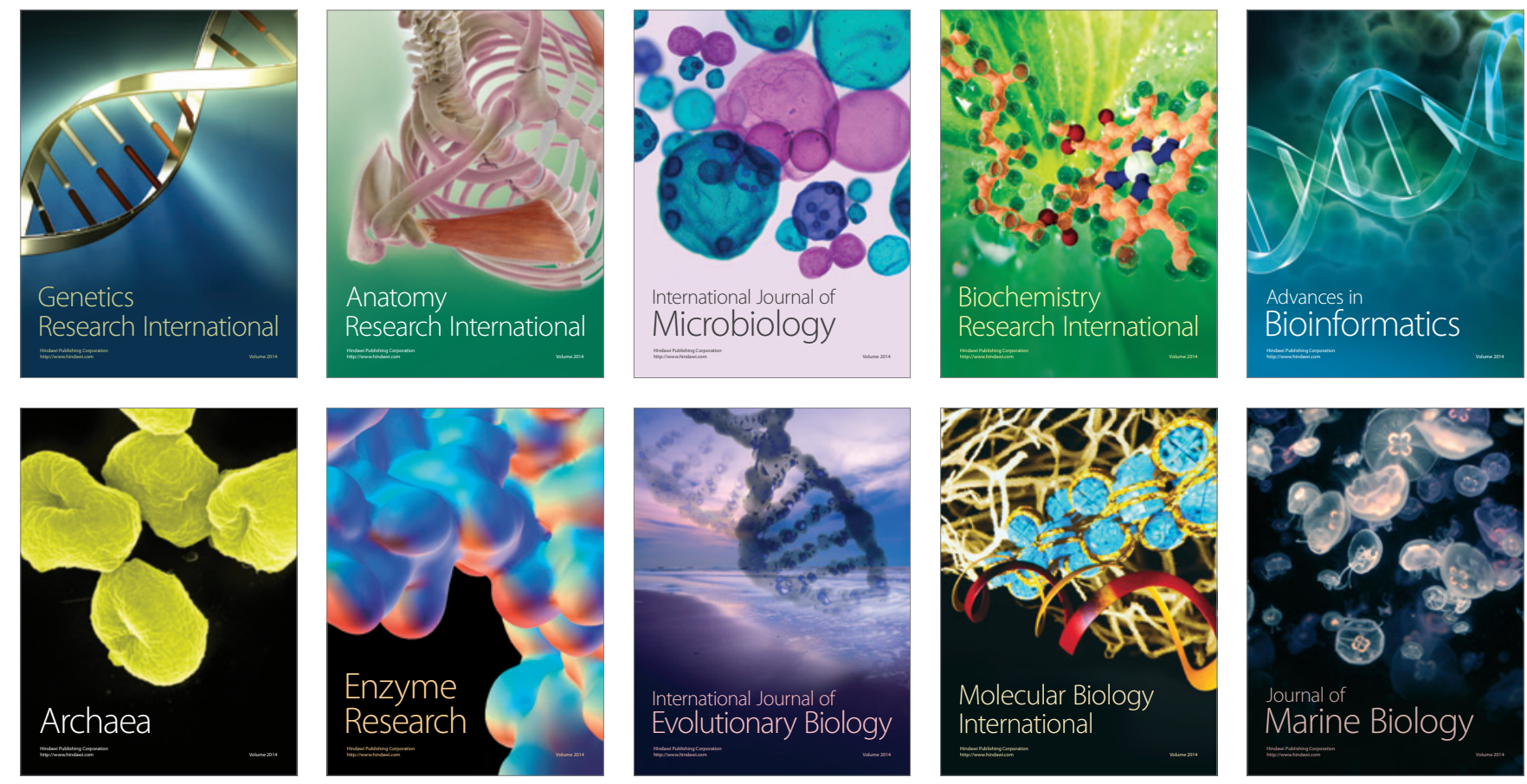